\title{
Unforeseen rib fracture findings in infant chest radiographs: evidence of non-accidental injury or simply a case of birth trauma?
}

\author{
Nyla Alam Khan, ${ }^{1}$ Vincent Lam, ${ }^{2}$ Andrew Rickett, ${ }^{2}$ Fiona Dickinson ${ }^{2}$
}

'Department of Radiology, Leicester Royal Infirmary, Leicester, UK

${ }^{2}$ Leicester Royal Infirmary Leicester, Leicester, UK

Correspondence to Dr Nyla Alam Khan, nyla.a.khan@gmail.com

Accepted 16 June 2016

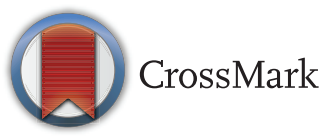

To cite: Khan NA, Lam V, Rickett $\mathrm{A}$, et al. BMJ Case Rep Published online: [please include Day Month Year] doi:10.1136/bcr-2016214651

\section{DESCRIPTION}

After a pregnancy complicated by gestational diabetes, a baby boy weighing $4.04 \mathrm{~kg}$ was born to a G1P0 mother. He was in cephalic occipitoanterior presentation; therefore a decision was made to deliver him by forceps. However, the delivery was further complicated by shoulder dystocia. On physical examination after birth, the attending doctor noted bruising to the child's face and ears, and reduced power in the right arm. A chest radiograph taken shortly after review demonstrated posterior rib fractures of the left fifth to seventh ribs (figure 1).

Owing to the instrumental delivery and birth trauma, a skeletal survey was not performed. Based on the known clinical history, the examination findings were attributed to injury sustained during delivery. Although rare, there have been multiple case reports of rib fractures in neonates occurring secondary to birth trauma. ${ }^{1}$ Fractures in a neonate presenting in a similar fashion to those in our case report are very unusual as they are usually deemed secondary to anteroposterior compression or direct

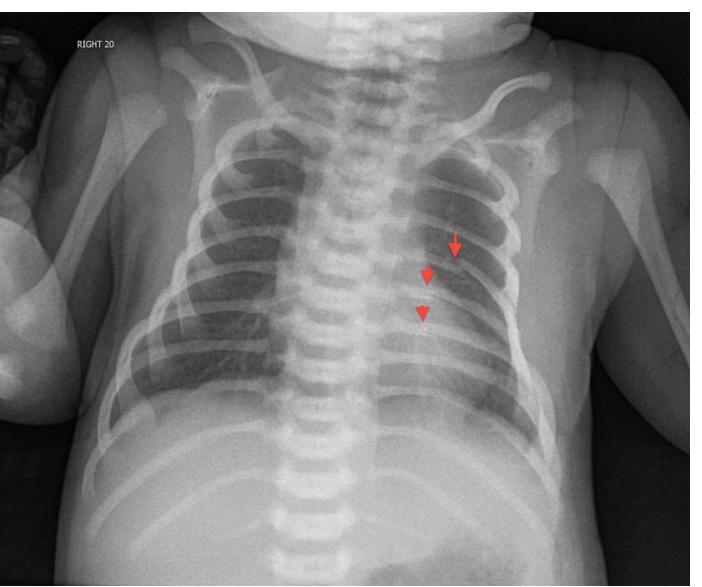

Figure 1 Chest radiograph demonstrating posterior fractures of the left fifth to seventh ribs. trauma to the chest wall-mechanisms that are usually associated with non-accidental injury (NAI). ${ }^{2}$ Specifically, posterior rib fractures are considered highly suspicious for NAI. ${ }^{3}$

Case reports such as ours highlight the need for succinct clinical history and examination to correlate with the relevant radiological findings. We also recommend undertaking relevant laboratory investigations to exclude metabolic diseases. In our case, blood tests revealed normal albumin, calcium, phosphate and alkaline phosphatase levels. The baby was therefore discharged with follow-up physiotherapy and an outpatient chest radiograph.

\section{Learning points}

- Rib fractures in a neonate or adolescent are highly suspicious for child abuse.

- Although rare, case reports have demonstrated that these findings have also been correlated with birth trauma.

- To aid with the correct diagnosis, imaging findings should be combined with clinical history, examination and laboratory findings.

Competing interests None declared.

Patient consent Obtained.

Provenance and peer review Not commissioned; externally peer reviewed.

\section{REFERENCES}

1 Durani Y, DePiero AD. Images in emergency medicine. Fracture of left clavicle and left posterior rib due to birth trauma. Ann Emerg Med. 2006;47:210, 215

2 Kleinman PK, Schlesinger AE. Mechanical factors associated with posterior rib fractures: laboratory and case studies. Pediatr Radiol 1997;27:87-91.

3 Carty H. Non-accidental injury: a review of the radiology. Eur Radiol 1997;7:1365-76.

Copyright 2016 BMJ Publishing Group. All rights reserved. For permission to reuse any of this content visit http://group.bmj.com/group/rights-licensing/permissions.

BMJ Case Report Fellows may re-use this article for personal use and teaching without any further permission.

Become a Fellow of BMJ Case Reports today and you can:

- Submit as many cases as you like

- Enjoy fast sympathetic peer review and rapid publication of accepted articles

- Access all the published articles

- Re-use any of the published material for personal use and teaching without further permission

For information on Institutional Fellowships contact consortiasales@bmjgroup.com

Visit casereports.bmj.com for more articles like this and to become a Fellow 